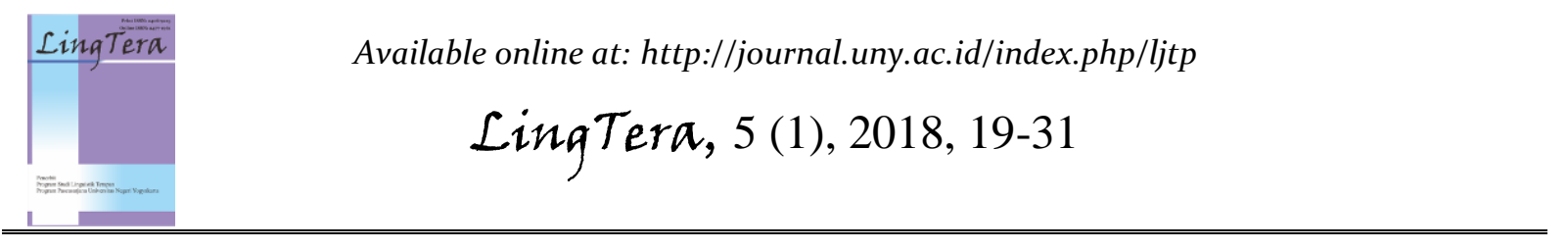

\title{
A Bahasa Indonesia-English translation analysis of Negeri Lima Menara and The Land of Five Towers
}

\author{
H. Hermawan *, Sufriati Tanjung \\ Department of Applied Linguistics, Program Pascasarjana, Universitas Negeri Yogyakarta. \\ Jalan Colombo No. 1, Karangmalang, Yogyakarta, 55281, Indonesia \\ * Corresponding Author. Email: her_mawan90@yahoo.co.id \\ Received: 24 February 2016; Accepted: 16 January 2018
}

\begin{abstract}
The objectives of this research were to describe the types of translation methods, to describe the types of translation procedures, to describe the changes in terms of added and reduced information, and to describe the types of cultural features found in The Land of Five Towers, compared to that of the original novel, Negeri Lima Menara. This research was a qualitative research. This qualitative research applied content analysis to analyse the data. The results of the research were as follows. (1) There were two translation methods found in this research, Semantic Method and Communicative Method. Semantic Method was proven to be the more dominant. (2) There were five translation procedures found: transposition, modulation, adaptation, contextual equivalence, and noted equivalence. Yet, the most prominent procedure applied was transposition. (3) Added information was made on: cultural expressions, names of places, and predicate of the sentences. (4) Reduced information was made on: names of Islamic scholars, arabic expressions, Indonesian expressions, etc. (5) There were five kinds of cultural features found, they were: ecology; material culture or artefacts; social culture; organisations, customs, activities, procedures, and concepts; and gestures and habits.
\end{abstract}

Keywords: translation phenomena, translation methods, translation procedures, added/reduced information, cultural features

How to Cite: Hermawan, H., \& Tanjung, S. (2018). A Bahasa Indonesia-English translation analysis of Negeri Lima Menara and The Land of Five Towers. LingTera, 5(1), 19-31. doi:http://dx.doi.org/10.21831/lt.v5i1.8065

http://dx.doi.org/10.21831/lt.v5i1.8065

\section{INTRODUCTION}

Translation has become more and more central in our daily life nowadays. This is caused by so many languages (around 7.000 different languages, according to BBC) which are being spoken and used by people throughout the world; also being demanded by the need of globalization era that requires us to understand foreign languages that we do not even know. By the existence of translation we are able to understand foreign languages that are produced either textually or orally; textual translation is commonly called by translation, whilst oral translation is called by interpretation.

A translator plays an important role in the process of translation. Since its a translator's job to endeavour to understand what the writer wishes to say and express, as it is stated by Samuelsson-Brown (2010), one has to be careful and thorough in translating a source text into target text. Even though the form changes, a translator needs to maintain the meaning of the source language when she/he translates a text or statement into the target language to avoid meaning distortion and the intended meaning is conveyed. This fits the definition of translation that translation consists of transferring the meaning of the source language into the receptor language (Larson, 1984, p.3).

Since translation is a process of meaning and realisation from one language to another, we cannot separate it from many aspects involved, especially language (or delivery) system and cultural aspect, for these two elements comprise the source of difficulty in translation (Anari \& Bouali, 2009, p.77). Some theories claim that a good translation product is the one which is accurate and natural. This takes a good translator who understands the languages and the cultures of both languages to translate. For example the words ramadhan and maghrib, these words are 
originally arabic, but because Indonesia is a country in which the population are majority Moslems (so that it has similar culture to Arab's) these words are easily understood. But if these words were to be translated into English without any further explanation, the original meaning of the words will not get to the readers. It happens because western culture is diffferent than that of the middle east.

Language system and culture difference could result in various phenomena to occur in the translated text. For example are sentences taken from Negeri Lima Menara and The Land of Five Towers:

Mukanya selalu mengibarkan senyum ke siapa saja. (ST)

Was translated into:

She smiled at everyone and everything. (TT)

The sentence in Indonesian explains what the author intended to say in a more dramatic way through the word mengibarkan, while in the English text, the translator reduced the dramatic sense by translating it into a mere smile. In addition to that, in Indonesian text it says ke siapa saja, but instead of translating it only at everyone, it was translated at everyone and everything. Thus the translator added words that can give different meaning to the sentence because in Indonesian word siapa only refers to human being that have the equivalent meaning as everyone in English, whereas everything refers to things that are inhuman. Then, there is the word selalu which if it is translated into English becomes always, that is experiencing reduction by an omission.

Furthermore, there is also another addition in the English translation, that is grammatical feature. Grammatical feature shown in the example is about tenses (time form) which does not exist in Indonesian. It can be seen from the word senyum which is translated into smiled. In Indonesian there is no time form such as in English, which makes it no difference when stating words for past, present or future; in English if one wishes to state something he/she has to consider the right time form. The word senyum does not indicate anything about when the event takes place, but the word smiled conveys an information which word senyum does not; that the event happened in the past. Hence, the translator added and reduced information from the sentence at the same time. Another example:
Aku mencanangkan untuk menambah ibadah dengan shalat sunat tahajjud setiap jam 2 pagi. (ST)

The translation was:

I declared that I would add an additional night prayer called Sunna Tahajjud at two o'clock every morning. (TT)

From the example shown, not only does it show language system difference as in the first example, but also cultural difference. It can be seen through the translation of shalat sunat tahajjud into additional night prayer called Sunna Tahajjud. In the translation, the translator added an information about what Sunna Tahajjud is, that is an additional prayer done at night. For Indonesian whose major religion is Islam, this thing can be understood easily, because it is in their culture. Yet, for those Target Text readers whose cultural and religion backgrounds are different, it would be difficult for them to comprehend. That is why an explanation is needed, in this case to clarify the meaning of the word, phrases, or sentences that contain cultural aspects.

Looking at the previous examples, it can be inferred that there are positive and negative aspects in the translated text compared to the original text. The positive aspect is shown through the language structure between the two tetxs. The translator seemed to try to translate the text as closely as possible to the original text in order to be accurate, to avoid meaning distortion and other translation errors. In the other hand, the negative aspect can be seen from how the translated text experiencing added and reduced information, although they were probably done by the translator to make the translation more natural and acceptable for the target text readers. This is similar as what has been stated by Hapsari \& Tou (2015) in her research, that there must be addition and reduction in the realisation done by translator in the process of translation. Nevertheless, translation phenomena are not limited on these positive and negative aspects. Other aspects that also occur in a translation are translation methods and translation procedures applied by the translator in translating the text.

These aspects had the researcher attracted in doing a research about them. Therefore, the researcher decided to do a research on the translation aspects in an Indonesian novel called Negeri Lima Menara by Ahmad Fuadi and its English translation, The Land of Five Towers by Angie Kilbane. Negeri Lima Menara was chosen 


\section{H. Hermawan, Sufriati Tanjung}

because it had gained its fame that it had been filmed and translated into several languages including English. The novel had been nominated as one of the best seller novel in Indonesia and grabbed Anugerah Pembaca Indonesia 2010 Award. It had also been nominated in the Top 10 Khatulistiwa Literary Award. Yet, it was chosen mainly because it contained many things which were parts of Indonesian culture, especially the culture of Madani Pesantren, that made it even more interesting to be compared with its English version.

Relating to the previous statements, the problems were identified as follows: (1) The importance of a good translator who masters the language and the culture of both texts to avoid an unaccepted translation. (2) The importance of meaning preservation of the Source Text (ST) in the Target Text (TT) to avoid meaning distortion. (3) Language system difference between Negeri Lima Menara (ST) and The Land of Five Towers (TT). (4) Cultural difference between Negeri Lima Menara (ST) and The Land of Five Towers (TT). (5) Various phenomena caused by the difference of language system and cultural aspect.

Therefore, this research had the objectives of describing the translation methods and procedures that are employed by the translator, describing the information changes that occur in the translated text, and describing the cultural features that are found in the translated text.

This research was focused and limited on the issue of the difference of the language system and cultural aspect between Negeri Lima Menara and its English translation, The Land of Five Towers. The language system could be seen through the words, phrases, clauses, and also sentences, which were the data units of the analysis. The analysis of the language system in both texts resulted in the findings of the translation methods and translation procedures applied by the translator, also added and reduced information. Cultural aspect was later be analysed to find out what kind of cultural features existed in the novels and how the realisations of the translations were.

Thus, from the discussion about how language system and cultural difference could affect a translation, the researcher had decided to analyse the translation methods, added and reduced information, translation procedures applied by the translator, and how cultural features were translated.
Finally, this research is hoped to have theoretical and practical benefits. Theoretically, the result of this research is hoped to be able to contribute to the developing of translation study, especially Indonesian (as a Source Text) and English (as a Target Text). Practically, the result of this research is hoped to provide a guideline for other researchers who put an interest in conducting a research on interlingual texts, also this research is hoped to provide an additional reference on how to conduct a similar research which focuses on finding out the dominant translation method, translation procedures applied, added/reduced information, and cultural features of a literature and its translation.

\section{METHOD}

This research was done with qualitative method. Qualitative research is a means for exploring and understanding the meaning individuals or groups ascribe to a social or human problem. The process of research involves emerging questions and procedures. Data typically collected in the participant's setting (Creswell, 2009, p.3). The purpose of this research was to explain the results of the analysis of Negeri Lima Menara and its English translation. The type of this research was content analysis due to what was analysed; the content of two texts (Negeri Lima Menara by Ahmad Fuadi and its English translation The Land of Five Towers by Angie Kilbane). Content analysis itself is any technique for making inferences by systematically and objectively identifying special characteristics of messages (Holsri in Berg, 2001, p.240).

This research was not limited on any specific time and location because this research was a library research. Thus, it was possible for the research to be conducted as long as the source of the data were available. The research activities included data reading, data input, re-reading the source of the data, data clasification, data analysis, data test by interrater, revision, and conclusion drawing.

This research was a translation research, so it involved at least two translational texts: Source Text (ST) and Target Text (TT). The two texts involved were categorised as literary texts. The Source Text in this research was an Indonesian novel entitled Negeri Lima Menara by Ahmad Fuadi that was first published in 2009. The Target Text was its English translation The Land of Five Towers translated by Angie Kilbane, and first published in 2011. 
The data of this research were not taken from the whole novels. It was only 15 random chapters taken from the two novels as the sample. The 15 chapters consisted of the first five chapters (chapter 1-5), five middle chapters (chapter 21-25), and the last five chapters (chapter 42-46).

To find out about the more dominant translation method employed by the translator, the analysis was done in sentence unit. To find out about the translation procedures applied, the analysis was done in sentence, clause, phrase, and word units. To find out about the added and reduced information, the analysis was done in sentence, clause, phrase, and word unit. To find out about words that contain cultural values, the analysis was done in clause, phrase, and word unit.

To obtain the data, the researcher read the Indonesian novel and its English translation, and tried to understand the content and the meaning of both sources. After that, the data from 15 chosen chapters were input and served in tables in order to be easier to be read, understood and analysed. As in the Table 1.
The instrument in this research was the researcher himself (human instrument) for he had the capability and knowledge pertaining to the focus of the research. In this research, the researcher played a very important role, he acted as the planner, practicioner, data collector, analyst, interpreter and also the one to report the results of the research. Stressing on how important human instrument is, Peredaryenko \& Krauss (2013) point out that it has its own uniqeness that lies in the notion that only people construct and bring meaning into the world through their qualities of sensitivity, responsiveness and flexibility, making them the most appropriate instrument for inquiries aiming to arrive at understanding, meaning, the promotion of critical awareness, emancipation, and movement toward deconstruction or decolonization.

In order for the content of the two texts involved to be easier to analyse, the researcher used these parameters as in Table 2 .

Table 1. Data Analysis of Negeri Lima Menara and The Land of Five Towers

\begin{tabular}{cccccccccccccc}
\hline \multirow{2}{*}{ Nu. } & $\begin{array}{c}\text { Source } \\
\text { Text }\end{array}$ & Page & $\begin{array}{c}\text { Target } \\
\text { Text }\end{array}$ & Page & & \multicolumn{3}{c}{ TM } & \multicolumn{1}{c}{ Information } & \multicolumn{1}{c}{ Translation Procedures } & Cultural \\
\cline { 5 - 11 } & & SM & CM & AL & RI & T & M & A & CE & NE & Features \\
\hline
\end{tabular}

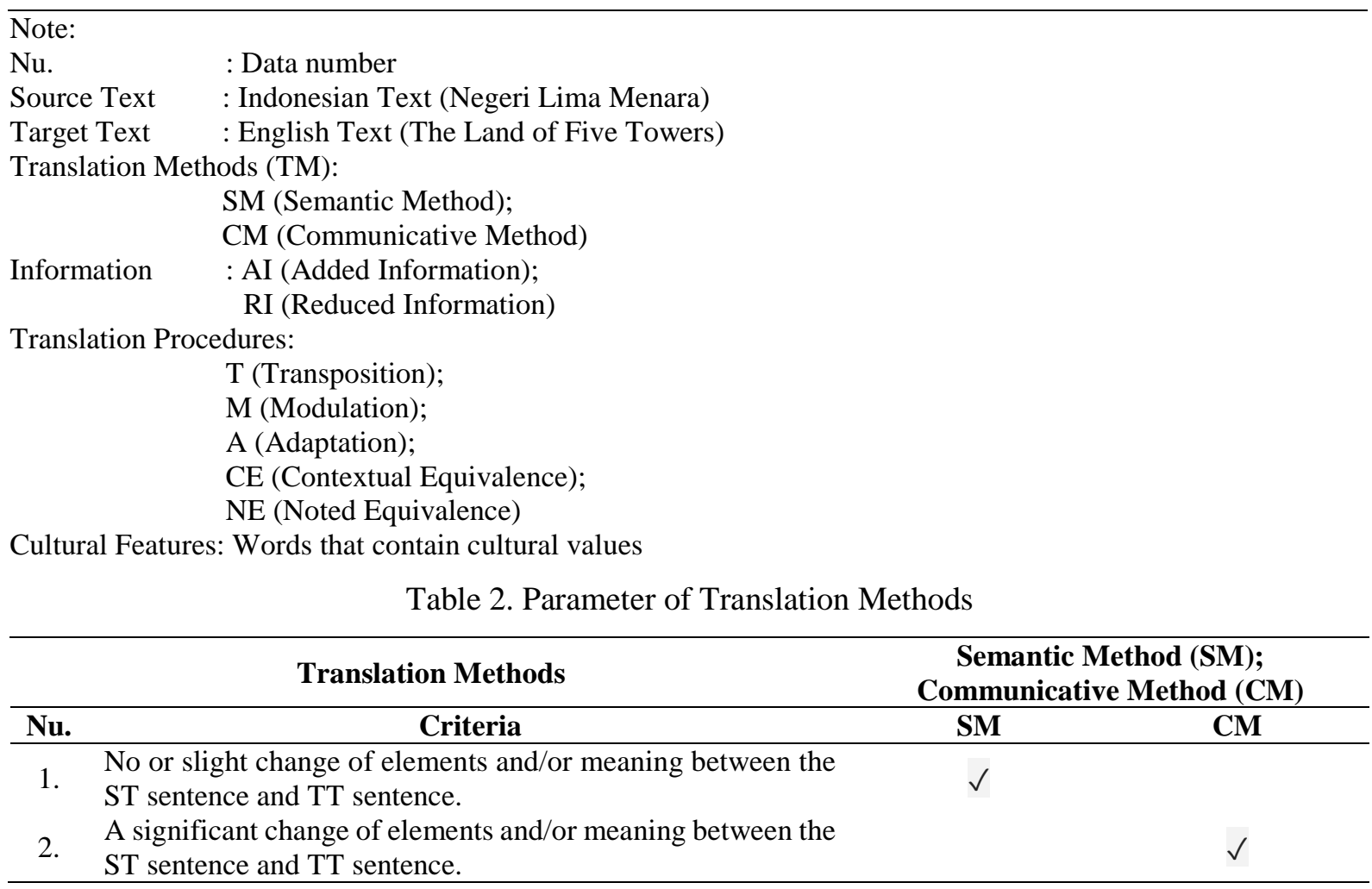


LingTera, 5 (1), 2018 - 23

H. Hermawan, Sufriati Tanjung

Table 3. Parameter of Translation Procedures

\begin{tabular}{clcccc}
\hline & \multicolumn{1}{c}{ Translation Procedures } & \multicolumn{3}{c}{ Transposition (T); Modulation (M); Adaptation (A); } \\
Contextual Equivalence (CE); Noted Equivalence (NE)
\end{tabular}

Table 4. Parameter of Added and Reduced Information

\begin{tabular}{clcc}
\hline & \multicolumn{1}{c}{ Added and Reduced Information } & \multicolumn{2}{c}{$\begin{array}{c}\text { Added Information (AI); Reduced } \\
\text { Information (RI) }\end{array}$} \\
\hline Nu. & \multicolumn{1}{c}{ Criteria } & AI & RI \\
\hline 1. & $\begin{array}{l}\text { Any addition in terms of meaning, intention, and } \\
\text { information. }\end{array}$ & $\checkmark$ & \\
$\begin{array}{l}\text { Any reduction in terms of meaning, intention, and } \\
\text { information. }\end{array}$ & & $\checkmark$ \\
\hline
\end{tabular}

Table 5. Parameter of Cultural Features

\begin{tabular}{|c|c|c|c|c|c|c|}
\hline \multicolumn{2}{|r|}{ Cultural Features } & \multicolumn{5}{|c|}{$\begin{array}{l}\text { Ecology (E); Artefact (A); Social Culture (SC); } \\
\text { Organisation, etc. (O); Gesture and habit (G) }\end{array}$} \\
\hline Nu. & Criteria & $\mathbf{E}$ & $\mathbf{A}$ & SC & $\mathbf{O}$ & G \\
\hline 1. & Anything related to geographical features. & $\checkmark$ & & & & \\
\hline 2. & $\begin{array}{l}\text { Anything created by man and is usually for } \\
\text { practical purpose. }\end{array}$ & & $\checkmark$ & & & \\
\hline 3. & $\begin{array}{l}\text { Social culture is something related to work and } \\
\text { leisure. }\end{array}$ & & & $\checkmark$ & & \\
\hline 4. & $\begin{array}{l}\text { Organisations, customs, activities, procedures, } \\
\text { and concepts talk about politics, religions, and } \\
\text { arts. }\end{array}$ & & & & $\checkmark$ & \\
\hline 5. & $\begin{array}{l}\text { Movements and habits in which they only exist } \\
\text { in ST culture but do not in TT culture. }\end{array}$ & & & & & $\checkmark$ \\
\hline
\end{tabular}

To obtain a valid research, this research used intrarater and interrater to test the validity of this research. An intrarater (the researcher) with perserverance in observation read and studied about the subject for several times to get sufficient data. In this case, the researcher carefully checked the obtained data many times to find as many data and relevant aspects in order to get accurate and detailed data. Before validity check by the interrater, the researcher went through peer reviewers first. There was one interrater asked for favor by the researcher to check the validity towards the interpretations that were done in the analysis. The data and analysis check by the interrater was not done only once, it was continuously done to achieve the same understanding between the researcher and the interrater about the research.
Technique used in this research was an equivalent method (metode padan). The purpose of applying this technique was to determine the identity of the object of the research. The identity of the research object was decided based on the degree of equivalence, harmony, suitability, compatibility and the similarity by means of determining device that is dealt with and at the same time becomes the standard (Sudaryanto, 2001, p.13). After the data were categorised, the data then be compared with its translation and the researcher tried to investigate the phenomena occured, including the translation type (semantic translation or communicative translation), the addition and reduction of informations, the translation procedures applied by the translator, and also cultural features. 


\section{FINDINGS AND DISCUSSION}

\section{Description of Research Findings}

This research involved two translational texts, Indonesian text (Source Text) and English text (Target Text). The two translational texts were in the forms of novels, thus they were categorised as literature texts. The title of the Indonesian text is Negeri Lima Menara, originally written by Ahmad Fuadi, whereas the title of the English version or the translated text is The Land of Five Towers, translated by Angie Kilbane.

From the total of fourty six chapters, there were only fifteen chapters taken as the sample which then be analysed and categorised in this research; the fifteen chapters consisted of the first five chapters, five middle chapters, and last five chapters. This research's data were in the unit of sentences, clauses, phrases, and words from Source Text and Target Text that had been compared, analysed, and categorised. Therefore, translation phenomena, in this case were translation methods, and translation procedures which were used by the translator can be determined, added/reduced information, and cultural features can be known. Below are the description of the findings in this research:

\section{Description of Translation Methods}

As it had been discussed on the previous chapter that this research applied Newmark's theory of translation methods; that there are eight translation methods in translation, four methods that side with Source Text (faithful translation, literal translation, word-for-word translation, and semantic translation as the head of translation methods under the Source Text), and four other methods that side with Target Text (idiomatic translation, free translation, adaptation, and communicative translation as the primary translation method under the Target Text). From the total of 15 chapters from each novels, the overall data were up to 237 data; 1944 data or $81.7 \%$ of which Semantic Method was applied on and 413 data or $17.9 \%$ of which Communicative Method was applied on, and 21 data or $0.9 \%$ of which both methods were not applied on. Therefore, it could be confirmed that Semantic Method was the more dominant method employed by the translator in the process of translating Negeri Lima Menara into The Land of Five Towers.

The results of the research had proven that the presumption made by the researcher was correct, that the translation of literary work would most prabably be Semantically translated than Communicatively. As Wang (2014) points out that:

"Genres that usually use the communicative translation method are news report, textbooks, public announcement and many other non-literary works. Semantic translation generally applies to literature, scientific and technical literature, and other genres that treat the original language and contents as important as the translated ones."

This also meant that The Land of Five Towers (Target text) sided more to Source Language than to Target Language.

\section{Description of Translation Procedures}

Referring to the concept of translation procedures, this thesis adopted the concept from Machali (2009), which proposes five types of translation procedures, namely: transposition (form shift), modulation (meaning shift), adaptation, contextual equivalence, and noted equivalence. These five procedures were all found in this research. From the analysis, Transposition or form shift was found in 1977 data; modulation or meaning shift was found in 395 data; adaptation was found in 233 data; contextual equivalence was found in 59 data; and noted equivalence was only found in 14 data. The most applied translation procedures were transposition and modulation because, as it had been stated before, they are closely related to the language systems. The difference in language system of two different languages could cause form shifting (transposition), and sometimes the form shifting could affect meaning shifting (modulation).

\section{Description of Added and Reduced Information}

As we know it, when translation is done from one language to another, it is inevitable that information-including meaning and intentionmight experience addition or reduction which is caused by many factors. Thus from 2378 data, the addition into the information in the translated text was found in almost all of the data, including gramatical features which do not exist in the Source Text yet exist in the Target Text, and some other kinds of addition. But, in the contrary, the reduction was only found in some of the data. The number of the data which experienced added information were 2295 data, whereas the number of the data that experienced reduced information were only 440 data. 


\section{Description of Cultural Features}

According to Newmark (1988), there are five categories that should be noted in translation pertaining to cultural features, they are: ecology; material culture (artefacts); social culture; organisations, customs, activities, procedures, concepts; and gestures and habits.

After the analysis was conducted on cultural features that exist in Indonesian culture, the results were as follows: (a) There were 348 data found related to Ecology; (b) There were 190 data that could be categorised as material culture or artefacts; (c) There were 125 data which showed the concept of social culture; (d) There were 44 data pertaining to the organisations, customs, activities, procedures, and concepts; and (e) There were 58 data showing gestures and habits.

\section{Discussion}

The aims of this research were to describe about translation phenomena occured in two novels called Negeri Lima Menara by Ahmad Fuadi, as the Source Text, and its English translation The Land of Five Towers by Angie Kilbane, as the Target Text. The translation act between these two novels was categorised as interlingual translation, because it involved two texts from two different languages. The difference of the two languages caused translation phenomena to take place. In this research, the so-called translation phenomena covered four major aspects, they were: (1) translation methods applied by the translator (2) translation procedures employed (3) added and reduced information and (4) cultural features.

Translation Methods

In this research, the researcher looked up to Newmark's concept of translation methods. In his concept, he proposes eight types of translation which is differentiated in two main translation types: Semantic Translation-or Semantic Method, the term used in this research-which emphasises on Source Language (including faithful translation, literal translation, and word for word translation) and Communicative Translation-or Communicative Method-which emphasises on Target Language (including idiomatic translation, free translation, and adaptation).

\section{Semantic Method}

Semantic method preserves the translated text within the nature of the Source Text. Thus, sometimes the translation tends to be more complex, more awkward, more detailed, more concentrated, and pursues the thought-process rather than the intention of the transmitter. It also tends to over-translate, to be more specific than the original, to include more meanings in its search for one nuance of meaning. From the total of 2378 data, 1944 data $(81.7 \%)$ tended to be translated with Semantic Method.

Here was a datum which showed the employment of Semantic Method.

\section{Datum 1}

ST: Aku suka dan benci musim dingin. (p. 2)

TT: I love and hate winter. (p. 2)

If the two sentences of Datum 1 were parsed, it could be seen as follows:

\begin{tabular}{ccccc}
\hline$A k u$ & suka & dan & benci & musim dingin \\
\hline $\mathrm{I}$ & love & and & hate & winter \\
\hline
\end{tabular}

From the table, it was clear that there was no difference between the Source Text and Target Text in terms of word order. There was not even a slightest change made by the translator, except for the language. This was done because there was no need for it; the meaning was clear and conveyed well. Therefore, the translation method applied was Semantic Method, for it delivered meaning into Target Text in a way that the translator was faithful with the Source Text.

\section{Communicative Method}

In contrast with Semantic Method, Communicative Method tends to side with Target Language. It reconstructs texts from Source Text in a way that the readers of the Source Language will not find any difficulties or unclear messages when they read the translation. This translation mostly feels natural for the Target Text readers, because it emphasises on the meaning transfer rather than the realisation. There were 413 data (17.4\%) which employed this method in this research.

Here was a datum in which Communicative Method was applied on:

\section{Datum 2}

ST: Kantorku berada di Independence Avenue, jalan yang selalu riuh dengan pejalan kaki dan lalu lintas mobil. Diapit dua tempat tujuan wisata terkenal di ibukota Amerika Serikat, The Capitol and The Mall, tempat berpusatnya aneka museum Smithsonian yang tidak bakal habis dijalani sebulan. (p. 2)

TT: Independence Avenue-the street of my office always hectic with pedestrians and car trafficis sandwiched between two famous tourist 


\section{LingTera, 5 (1), 2018 - 26}

\section{H. Hermawan, Sufriati Tanjung}

attractions in Washington: The Capitol and The Mall, the center of the various Smithsonian museums all of which, even if you had a month, you wouldn't be able to see. (p. 2)

The first thing to be noticed from Datum 2 was the structure change which lead to perspective change-yet the the information remained unchanged. In the Source Text, there were two sentences, but the translator merged the originally two sentences into one long sentence. The translator seemed to think that there was no need to translate it semantically, for the two sentences contained the same information. Further, the main intention of the author of the Source Text was to tell the readers about the location of the office. Instead of doing the same thing with the translation, the translator changed the focus of the sentence that the main intention was fixed on talking about Independence Avenue.

The last part of the sentence was also experiencing a structure change; the Source Text said "... aneka museum Smithsonian yang tidak bakal habis dijalani sebulan" if it were translated literally (or semantically) it would be "... various Smithsonian museums which you won't finish to see in a month". Instead, she translated it into "... various Smithsonian museums all of which, even if you had a month, you wouldn't be able to see", which meant "aneka museum Smithsonian yang, bahkan jika kamu memiliki waktu sebulan, tidak akan bisa selesai dilihat". This indicated that datum 2 employed Communicative Method.

Translation Procedures

Procedures of translation are different than those of methods of translation. The difference is on the unit of where they are applied on. Methods of translation are related to the text as a whole, but procedures of translation are applied on the smaller units, that is sentence, or even smaller such as clause, phrase, and word.

\section{Transposition}

Transposition or simply called form shifting was the most common procedure found in the analysis. This was due to the difference of the language system of the two languages. Below, was a datum showing transposition:

\section{Datum 3}

ST: Masa yang sangat kuat terpatri dalam hatiku. (p. 4)

TT: A very strong period etched in my heart. (p. 4)
Transposition occurred on datum 3 in two places, in the beginning of the sentence and at the end of the sentence. This was, as it had been said, due to the difference of the language system. If they were to be translated literally or through word-for-word translation, the language system would not allow them. The translation would become inexplicable. In the language system of Bahasa Indonesia noun comes before adjective as in "Masa yang sangat kuat", but in the language system of English, adjective is to be put first before noun. That was why the translation became "A very strong period". This phenomena is commonly known as DM-MD. Another similar case was also found in the last part of the sentence, that was on the translation of "hatiku" into "my heart". All kinds of noun followed by possession has to be translated in English reversely.

\section{Modulation}

This translation procedure is used when literal translation cannot result a natural translation. in this case, a translator needs to view the translation from a different perspective. Modulation is divided into free modulation and obligatory modulation. An example of free modulation of this research could be seen from the datum below.

\section{Datum 4}

ST: Televisi di ujung ruang kantor menayangkan Weather Channel yang mencatat suhu di luar minus 2 derajat celcius. Lebih dingin dari secawan es tebak di Pasar Ateh, Bukittinggi. (p. 2)

TT: The television at the end of the office showed the Weather Channel, displaying a temperature of minus two degrees Celsiusdefinitely colder than a glass of shaved ice made by a spinning machine in my village in West Sumatra. (p. 2)

Datum 4 showed an interesting translation. The words in bold between the Source Text and Target Text indicated an explicitation. "secawan es tebak" was translated into "a glass of shaved ice made by a spinning machine". Not only did the translator let us know what es tebak is, she also added an information about how es tebak is made. It is usually done when the translator is afraid if the Target Text readers cannot understand words that contain cultural aspect, also to clarify the meaning and to seek for natural equivalence. The explicitation made by the translator in this datum is called free modulation. 
The following datum was taken from the analysis which showed the employment of obligatory modulation.

\section{Datum 5}

ST: Dia mengangkat telunjuk ke atas tanpa suara, menyuruhku menunggu. (p. 13)

TT: He lifted his index finger not saying a word, ordering me to wait. (p. 12)

An obligatory modulation was done on the translation of "Dia" into "He". Dia in Bahasa Indonesia does not refer to any specific gender, it could be male, female, or even transvestite, yet when it is translated into English, it experiences implicitation. He in English refers to a specific gender, that is male. Thus, sometimes translators do not realise that he/she applies this translation procedure, for it is already in the language.

\section{Adaptation}

Through adaptation, it is possible to create more natural translation, for adaptation is an effort of the translator to find the cultural equivalence between two certain situations in which the concepts of the Source Text and Target Text are different. The datum of adaptation found in this research was:

\section{Datum 6}

ST: Tiga tahun aku ikuti perintah Amak belajar di madrasah tsanawiyah, sekarang waktunya aku menjadi seperti orang umumnya, masuk jalur non agama-SMA. (p. 5)

TT: For three years I'd followed the orders of my Amak to study at an Islamic junior high school, and now was the time for me to be like the rest and take the nonreligious route-public high school. (p. 5)

Adaptation was done to translate "madrasah tsanawiyah" and "SMA". She translated those words into "Islamic junior high school" and "public high school". Madrasah tsanawiyah, indeed, is a junior high school for Moslem kids, and SMA-stands for Sekolah Menegah Atas-is a public high school. The translator had done a great job in finding the closest English equivalence for them. This could also be related to the concept of school itself. Each country has its own concept of schools and their names, so it allows translators to easily find the equivalence.

\section{Contextual Equivalence}

Due to the cultural difference between the Source Text (Bahasa Indonesia) and Target Text
(English), there must be words, phrases, clauses, or even sentences which make no sense for the readers of the Target Text. Therefore, this procedure can provide a solution for that problem. It gives more understanding and explanation about the words, phrases, clauses, and sentences that may cause confusion for the Target Text readers. The translator of the novel Negeri Lima Menara appeared to understand about this problem. Thus, she applied contextual equivalence to translate the datum below.

\section{Datum 7}

ST: Terdengar suara Sazli Rais yang berat membuka acara Dunia Dalam Berita TVRI. (p. 6)

TT: The news anchor's heavy voice was opening the World News on TVRI, the State-owned TV channel. (p. 6)

Contextual equivalence was done by the translator in translating TVRI. TVRI is the name of the State-owned TV channel in Indonesia. Since it could not be translated as it was without confusing the Target Text readers, the translator added the context of TVRI. It was done in order to make the information clearer.

\section{Noted Equivalence}

The last procedure proposed by Machali is noted equivalence. This procedure is slightly different with contextual equivalence; it allows the readers of the Target Text to experience words, phrases, clauses, and sentences of the Source Target (called foreignisation). In the translated novel of The Land of Five Towers, which was the subject of this research, the translator used noted equivalence by placing small numbers at the end of the words, phrases, clauses, or sentences that she considered requiring further explanations-the explanations were presented on the bottom page of where the numbered words, phrases, clauses, and sentences existed. Here was an example of noted equivalence:

\section{Datum 8}

ST: Aku ingin kuliah di UI, ITB dan terus ke Jerman seperti Pak Habibie. (p. 8)

TT: I wanted to attend university at the University of Indonesia, the Bandung Institute of Technology, and continue on to Germany, like Mr. B.J. Habibie ${ }^{3}$. (p. 8)

Added and Reduced Information

Because of the difference of the culture and language system, it is inevitable for the 


\section{LingTera, 5 (1), 2018 - 28}

\section{H. Hermawan, Sufriati Tanjung}

translated text, in this case is English, not to experience any changes. The changes analysed in this research were in the form of added and reduced information. Added and reduced information itself was related to the meaning, intention, and information changes done by the translator.

\section{Added Information}

Added information found in the analysis consisted of the addition of grammatical features in English (Target Text) which do not exist in Bahasa Indonesia (Source Text) and addition of words which caused meaning changes.

\section{Grammatical Features}

The addition of grammatical features in the analysis included tenses and articles, all of which are not present in Bahasa Indonesia.

Tenses

A tense is a part of English language features that indicates the time of an action. such as follows:

\section{Datum 9}

ST: Sambil mengguncang-guncangkan telapak tanganku, Pak Sikumbang, Kepala Sekolahku memberi selamat karena nilai ujianku termasuk sepuluh yang tertinggi di Kabupaten Agam. (p. 5)

TT: Mr. Sikumbang, my principal, shook my hand and congratulated me because my exam score was in the top 10 in Aagam Regency. (p. $5)$.

The sentence from the Source Text did not show any clue about when the act happened, because there was no adverb of time in it. Yet, in the Target Text, even though there was no adverb of time as well, it could be known that the act happened in the past through the words "shook", "congratulated", and "was", all of which were categorised as simple past verbs or the second form of the verbs which were used to tell about past activities.

\section{Articles}

Article means a word used to modify a noun, which is a person, place, object, or idea. The nature of article is similar to that of a tense, that is, does not exist in Bahasa Indonesia but exists in English, and the use of it is a must. Here was an addition found related to articles.

\section{Datum 10}

ST: Matahari sore menggantung condong ke barat berbentuk piring putih susu. (p. 1)
TT: The afternoon sun hung toward the west like a milky white plate. (p. 1)

As it could be seen that in the Target Text there were some additions which were not present in the Source Text; all of which were called articles. The first article was "the" and the second one was "a"; "the" is called definite article because it refers directly to a specific noun or groups of nouns, on the contrary "a" is called indefinite article and it does not refer to any specific noun. "The" was added before "afternoon sun" and "west" because these two things referred to one concept that everyone in the world knew. While "a" was added before milky white plate because it had no specific concept.

\section{Meaning Addition}

Whenever a language is transferred into another there must be changes happen. One of the changes could be meaning addition, which means something is added that may (or not) affect the translation.

\section{Datum 11}

ST: Nilaiku adalah tiket untuk mendaftar ke SMA terbaik di Bukittinggi. (p.5)

TT: My grades were my ticket to enroll at Bukittinggi State High School, the best in Bukittinggi, the capital of my regency. (p. 5)

It could be seen that the translator added more information about what Bukittinggi was. This was done because she seemed to think that the English readers would not be able to tell what Bukittinggi was. As the result, she added more information as the explanation.

\section{Reduced Information}

Beside added information there were also reduced information that happened to the translated text. This kind of phenomena always happens when translation act is done. As Sokolovsky (2010) said that information loss, or in this research is called reduced information, in translation is inevitable. The following was a datum that experienced reduction of information.

\section{Datum 12}

ST: Ayahnya atau kakekku yang aku panggil Buya Sutan Mansur adalah orang alim yang berguru langsung kepada Inyiak Canduang atau Syekh Sulaiman Ar-Rasuly. Di awal abad kedua puluh, Inyiak Canduang ini berguru ke Mekkah di bawah asuhan ulama terkenal seperti Syeikh Ahmad Khatib Al- 
Minangkabawy dan Syeikh Sayid Babas ElYamani. (p. 7)

TT: Her father, my grandfather, who I call Buya Sutan Mansur, was a pious man and a student of Syekh Sulaiman Ar-Rasuly, a famous cleric who studied in Mecca at the beginning of the 20th century. (p. 7)

The translator did not translate Inyiak Canduang into the Target Text and merged two long sentences from the Source Text into one by applying communicative method. The main information was preserved-the information about the author's religious grandfather named Buya Sutan Mansur who learnt his knowledge from his teacher named Syekh Sulaiman Ar-Rasuly. But the reduction she made was rather bold, for she cut off half of the original text. The reduced text talked about who Syeikh Sulaiman Ar-Rasuly was and his teachers, whose names were Syeikh Ahmad Khatib Al-Minangkabawy and Syeikh Sayid Babas El-Yamani, who he had learnt his knowledge from. All of which was not considered important by the translator and was why the reduction made.

\section{Cultural Features}

This research only focused on cultural features that existed in the culture of the Source text, which was Indonesian culture. Using Newmark's categorisations, the cultural features found were as follows:

Ecology

This category is related to nature, geographical features, and the like of it (this could be flora, fauna, winds, plains, hills, etc). The datum regarding Ecology was found in:

\section{Datum 13}

ST: Rasanya tenteram, ajaib dan aneh. Mungkin karena sangat berbeda dengan alam kampungku di Danau Maninjau yang serba biru dan hijau. (p. 2)

TT: It feels serene, magical, and strange, maybe because it's so different than the blue and green landscape of my village on Lake Maninjau. (p. 2)

Lake Maninjau is a beautiful lake located in West Sumatra, and known as tourist destination. It has an area of $99.5 \mathrm{~km}^{2}$, being approximately $16 \mathrm{~km}$ long and $7 \mathrm{~km}$ wide. The average depth is $105 \mathrm{~m}$, with a maximum depth of $165 \mathrm{~m}$.
Material Culture (Artefacts)

Examples of material culture could be seen as in the datum below:

\section{Datum 14}

ST: Kalau keluar rumah selalu menggunakan baju kurung yang dipadu dengan kain atau rok panjang. Tidak pernah celana panjang. (p. 6)

TT: When leaving the house, she always wore baju kurung with a traditional wrap or skirt, never pants. (p. 6)

Baju kurung is a traditional costume, especially for woman, that can be found across Malaysia, Brunei, and some parts of Indonesia, mainly in Sumatra.

Social Culture

This category is related to work and leisure, and was found in the datum below.

\section{Datum 15}

ST: Jangan khawatir dengan banyaknya ustad yang mondar-mandir di asrama, tinggal tanya hal yang sama ke ustad yang berbeda. (p. 192)

TT: Never fear, with so many ustads going around, all we had to do was ask the same question to a different ustad. (p. 180)

Ustad is an arabic word used to refer to someone who is considered as an expert in religion. Even though it is derived from arabic, most of Indonesians know what it means. This happens because Indonesia is a country whose the majority of the populations are Moslems, and which culture are slightly similar to that of Arabia. In the novel, ustad is the calling for the teachers.

Organisations, Customs, Activities, Procedures, and Concepts

This category talks about politics, religions and arts, and was found in the following datum:

\section{Datum 16}

ST: Kantor Pengasuhan atau KP adalah kantor keamanan teratas di PM dan diawaki ustad senior yang sangat disiplin dan selalu memegang teguh aturan seperti hukum besi. (179)

TT: The Counseling Department-the CD-was the highest security office at MP and was manned by a senior ustad who was very disciplined and always strictly stuck to the rules. (p. 168) 


\section{LingTera, 5 (1), 2018 - 30}

\section{H. Hermawan, Sufriati Tanjung}

From Datum 16, it could be seen that the translator translated "Kantor Pengasuhan" into "The Counseling Department". In the novel, this department has the authority to issue rules and give punishments to the students who tried/already broke the rules. Thus, it could be categorised into political words.

Gestures and Habits

This category is related to what people do in their everyday life. Here was the datum of gestures and habits found in this research:

\section{Datum 17}

ST: Sebelum meninggalkan rumah, aku cium tangan Amak sambil minta doa dan minta ampun atas kesalahanku. (p. 14)

TT: Before leaving home, I kissed Amak's hand while asking for her prayers and forgiveness for my mistakes. (p.14)

In Indonesian culture, kissing the hands of the parents means that the children love and respect them, which the people of the West do not do. In the contrary, in western countries, kissing someone's hand is only done by lovers. Therefore, the translator should give more explanation on that particular culture difference in order for the English readers to be able to understand it fully.

\section{CONCLUSION AND SUGGESTIONS}

\section{Conclusion}

From the total of 15 chapters from each novels, the total of the data, which were in the units of sentences, were up to 2378 data. 1944 data or $81.7 \%$ indicated the employment of Semantic Method. 413 data or $17.4 \%$ indicated the employment of Communicative Method was applied on. 21 data or $0.9 \%$ indicated that none of the methods were employed. Therefore, it could be confirmed that Semantic Method was the most dominant method employed by the translator in the process of translating Negeri Lima Menara into The Land of Five Towers. This also meant that The Land of Five Towers (Target text) sided more to Source Language than to Target Language.

In translating the novel Negeri Lima Menara into The Land of Five Towers, the translator must have applied several translation procedures. The translation procedures were used as the means to assist her overcoming the problems that occurred in the process of translation. Adopting a scholar's translation procedures, there were five kinds of translation procedures found in Negeri Lima Menara that had been compared to The Land of Five Towers, they were: transposition or form shift (found in 1977 data), modulation or meaning shift (found in 395 data), adaptation (found in 233 data), contextual equivalence (found in 59 data), and noted equivalence (found in 14 data). It could be summarised that the most prominent translation procedure found in The Land of Five Towers was transposition. This happened due to the nature of the language system of Bahasa Indonesia and English that the translator had to apply it.

Out of 2378 data, it was believed that 2295 data experienced addition of information-information in this research also included meaning and intention. The addition occurred in the form of grammatical features, including tenses and articles. The added information given by the translator were mainly to create an equivalence in the Target Text and to clarify cultural word(s) so that the Target Text readers would not get missunderstanding. Added information were made on: cultural expressions, names of places, and predicate of the sentence.

From the total of 2378 , there were 440 data experiencing reduction of information. The reduction occured on the words, phrases, clauses, and sentences that were considered insignificant by the translator, but it was based on consideration that by reducing them the intended meaning of the text still could get to the readers of the Target Text. The reduced information was made on: names of Islamic scholars, arabic expressions, Indonesian expressions, etc.

Cultural features found in the data analysis were ecology (found in 348 data); material culture or artefacts (found in 190 data); social culture (found in 125 data); organisations, customs, activities, procedures, and concepts (found in 44 data); and gestures and habits (found in 58 data).

\section{Suggestions}

Based on the research that had been conducted, suggestions could be drawn as follows: For translators, cultural aspect and language system cannot be separated with translation, in which they become the problems that need to be overcome in interlingual translation, for not all cultural aspect and language system of Source Language have their equivalence in the Target Language. One of the solutions is that translators have to be deliberate in applying translation methods; whether the translation should lean towards Source Language or Target Language. 


\section{LingTera, 5 (1), 2018 - 31}

H. Hermawan, Sufriati Tanjung

Translators also have to be deliberate in applying translation procedures, because instead of creating a good translation, they could cause meaning distortion if they do it carelessly. Translators have to be careful in maintaining the meaning of the translation; for this could lead to addition and reduction of information. Finally, in translating cultural features, translators need to be really wise to find their closest equivalence in order to achieve natural and accurate translation.

This research is still limited only on the description of translation methods, added and reduced information, translation procedures, and cultural features. While to those who are interested in conducting similar research could use the same kind of research but more deeply. They could try to figure out why these kind of phenomena occur so the research can be richer in terms of information.

\section{REFERENCES}

Anari, S.M., \& Bouali, Z. (2009). Naturalness and accuracy in English translation of Hāfiz. Journal of Teaching English as a Foreign Language and Literature. Retrieved on 03 January 2016 from http://www.sid.ir/en/vewssid/j_pdf/10182 20090305.pdf

Berg, B.L. (2001). Qualitative research methods for the social sciences. Needham Heights: A Pearson Education Company.

Creswell, J.W. (2009). Research design: Qualitative, quantitative, and mixed methods approaches ( $3^{\text {rd }}$ ed.). California: SAGE Publications, Inc.

Hapsari, A., \& Tou, A. (2015). Variasi keluasan makna interpersonal teks "Laskar Pelangi" berbahasa Indonesia, Inggris, dan Melayu. LingTera, $2(1), \quad 12 \quad-\quad 26$. doi:http://dx.doi.org/10.21831/lt.v2i1.540 2
Larson, M. (1984). Meaning-based translation: A guide to cross-language equivalence. Lanham, MD: University Press of America.

Machali, R. (2009). Pedoman bagi penerjemah. Bandung: Kaifa.

Newmark, P. (1988). A textbook of translation. New York: Prentice Hall Inc.

Peredaryenko, M.S., \& Krauss, S.E. (2013). Calibrating the human instrument: Understanding the interviewing experience of novice qualitative researchers. The Qualitative Report 2013 Volume 18, Article 85, 1-17. Retrieved on 05 January 2016 from https://www.nova.edu/ssss/QR/.../peredar yenko85.pdf

Samuelson-Brown, G. (2010). A practical guide for translators. Bristol: Short Run Press Ltd.

Sokolovsky, Y.V. (2010). On the linguistic definition of translation. Journal of Siberian Federal University. Humanities \& Social Sciences 2 (2010 3) 285-292. Retrieved on 07 January 2016 from http://elib.sfu-

kras.ru/bitstream/2311/1608/1/13_sokolo vskiy.pdf

Sudaryanto. (2001). Metode dan aneka teknik analisis bahasa. Yogyakarta: Duta Wacana University Press.

Wang, M. (2014). A study on semantic and communicative translation of magical things in Harry Potter. Studies in Literature and Language, Vol. 8, No. 2, 2014, pp. 26-31. Retrieved on 04 January 2016 from http://www.cscanada.net/index.php/sll/arti cle/download/4353/5781 